\title{
Dissemination of salt tolerant wheat varieties through frontline demonstrations approach for sustainable wheat production in Pali district of Rajasthan
}

\author{
Moti Lal Meena* and Dheeraj Singh \\ ICAR-CAZRI, Krishi Vigyan Kendra, Pali-Marwar (Rajasthan) 306401
}

\section{Article history}

Received: 16 Feb., 2019

Revised: 18 Feb., 2020

Accepted: 10 Mar., 2020

\section{Citation}

Meena ML and D Singh. 2020. Dissemination of salt Tolerant wheat varieties through frontline demonstrations approach for sustainable wheat production in Pali district of Rajasthan. Journal of Cereal Research 12(1):61-68. http://doi. org/10.25174/2582-2675/2020/87064

\section{*Corresponding author}

Email:mlmeenacazri@gmail.com

\begin{abstract}
Front line demonstrations (FLDs) on wheat were laid down at 465 farmers' fields to demonstrate production potential and economic benefits of improved production technologies comprising salinity tolerance varieties namely KRL 210, KRL 213, KRL 19 and KRL 1-4 in Pali district of arid zone of Rajasthan state during Rabi seasons from 2012-13 to 2017-18 in irrigated farming situation. The findings of the study revealed that the improved production technologies recorded an additional yield ranging from 7.1 to $16.0 \mathrm{qha}^{-1}$ with a mean of $11.1 \mathrm{qha}^{-1}$. The per cent increase yield under improved production technologies ranged from 22.5 to 52.9 (KRL 210), 25.6 to 45.2 (KRL 213), 26.6 to 47.7 (KRL 19) and 33.8 to 45.5 (KRL 1-4) in respective years. The average extension gap, technology gap and technology index were $11.1 \mathrm{qha}^{-1}, 11.3 \mathrm{qha}^{-1}$ and 24.4 per cent, respectively in different salt tolerance varieties of wheat. The improved production technologies gave higher benefit cost ratio ranging from 2.0 to 3.0 with a mean of 2.4 as compared to local checks (1.8) being grown by farmers under locality. The results revealed that the maximum number of the respondents had medium level of knowledge and extent of adoption regarding recommended wheat production technology. The study reported lack of suitable salt tolerance HYV as major constraints by beneficiaries at rank first followed by low technical knowledge. Thus the productivity of wheat per unit area could be increased by adopting feasible scientific and sustainable management practices with a suitable salt tolerance variety.
\end{abstract}

Keywords: Adoption, constraints, impact, FLD, salt affected soils, technology, wheat food crop production. If efforts are made to evolve and introduce a scientific crop planning in the saline affected areas, it should be possible to increase wheat productivity sustainability. Higher salinity delayed and reduced germination percentage (Ramden et al. 2012). Salinity decreased germination per cent, root length, callus size, coleoptiles length and seedling growth (Lallu and Dixit 2005; Ghannadha et al. 2005; Bera et al. 2006 and Agnihotri et al. 2006). Plant height, stem diameter, dry weight decreased with increasing levels of salinity. For increasing wheat productivity in salt affected area, it is necessary to make more intensive efforts for evolving soils are good and do not constitute any restriction for 
suitable salt tolerant varieties of wheat like KRL 210, KRL 213, KRL 19 and KRL 2-4 which was tolerant saline (EC 5-7 $\mathrm{ds} \mathrm{m}^{-1}$ ) as well as alkaline soil ( $\mathrm{pH}$ 8.7-9.3). Wheat is one of the important cereals crop grown in Rabi season grown in all over the Rajasthan. Area, production and productivity of wheat crop during 2017-18 in Pali district was $46550 \mathrm{ha}, 14725$ metric tons and $3152 \mathrm{~kg}$ per ha, respectively (GOR 2017-18). The productivity of wheat (2017-18) is comparatively low in Rajasthan (3112 kg/ ha) than other wheat cultivated states such as Haryana (5030kg/ha) and Punjab (4898 kg/ha).

Frontline demonstration is the new concept of field demonstration evolved by the Indian Council of Agriculture Research (ICAR) with main objective to demonstrate newly released crop production and protection technologies and its management practices in the farmers' field under different agro-climatic regions of the country under different farming situations. While demonstrating the technologies in the farmers' field the scientists are required to study the factors contributing higher crop production, field constraints of production and thereby generate production data and feedback information. Taking into account the above considerations FLDs were carried out in a systematic manner on farmer's field to show the worth of a new variety and convincing farmers to adopt improved production management practices of wheat for enhancing productivity of wheat. The low productivity of this crop is due to poor adoption of improved technologies of wheat by the farmers. Hence, the Krishi Vigyan Kendra, Pali has organized frontline demonstrations (FLD's) with improved salt tolerant variety along with recommended package of practices. The main purpose of these demonstrations was to enhance the productivity levels of wheat which in turn will increase the income levels of farmers and to transfer the latest production technologies to farmers in the district. Pali district is located between 24.45 to 26.75 degree $\mathrm{N}$ latitude and 72.48 to 74.20 degree $\mathrm{E}$ longitude at an altitude ranging between $212 \mathrm{~m}$ to about $220 \mathrm{~m}$ above mean sea level with a total geographical area of 12,387 square kilometers. In Pali district wheat traditionally grown as a Rabi crop. The regions are biotic, abiotic, and socio-economic constraints causing low productivity in pulses in this region. In addition, lack of improved varieties is reported as most serious constraints among all biophysical constraints in pulses production. While demonstrating the technologies in the farmer's fields, the scientists are required to study the factors contributing higher crop production, field constraints of production and thereby generate production data and feedback information. Taking into account the above considerations, frontline demonstrations (FLDs) were carried out in a systematic manner on farmer's field to show the worth of a new variety and convincing farmers to adopt improved production management practices of wheat for enhancing productivity.

\section{Materials and methods}

The study was conducted in farmers' fields to demonstrate production potential and economic benefits of improved technologies in Pali district arid zone of Rajasthan state during Rabi seasons from 2012-13 to 2017-18 in irrigated farming situation. To popularize the improved wheat production practices, constrains in wheat production were identified though participatory approach. Preferential ranking technique was utilized to identify the constraints faced by the respondent farmers in wheat production. Farmers were also asked to rank the constraints they perceive as limiting production factor for wheat cultivation in order of preference. Based on top rank farmers problems identified, front line demonstrations were planned and conducted at the farmer's fields. In all, 464 full package frontline demonstrations were conducted to convince them about potentialities of salt tolerant varieties of wheat viz., KRL 210, KRL 213, KRL 19 and KRL 1-4 during Rabi seasons from 2012 to 2018 under irrigated farming condition, in light to medium soils with low to medium fertility status under wheat-mungbean cropping systems. Each demonstration was conducted in an area of 0.4 ha and adjacent to the farmer's fields in which the crop was cultivated with farmer's practice/ local variety. The package of practices included were improved varieties, seed treatment, maintenance of optimum plant stand, recommended fertilizers dose, plant protection measures especially termite management. The spacing followed was at $15 \mathrm{~m} \mathrm{x} 10 \mathrm{~cm}$ sown between first week of November during the five years with the seed rate of $100 \mathrm{~kg} / \mathrm{ha}$. All the participating farmers were trained on all aspects of wheat production management. To study the impact of front line demonstrations, out of 464 participating farmers, a total of 160 farmers were selected as respondent through 
proportionate sampling. Production and economic data for FLDs and local practices were collected and analyzed. The Extension gap, technology gap and technology index were calculated using the formula as suggested by Samui et al. (2000).

Extension gap $\left(\mathrm{qha}^{-1}\right)=$

Demonstration yield $\left(\mathrm{qha}^{-1}\right)$-Yield of local check $\left(\mathrm{qha}^{-1}\right)$

Technology gap $\left(\mathrm{qha}^{-1}\right)=$

Potential yield $\left(\mathrm{qha}^{-1}\right)$ - Demonstration yield $\left(\mathrm{qha}^{-1}\right)$.

Technology index $(\%)=$

$$
\frac{(\text { Potential yied-Demonstration yield })}{(\text { Potential yield })} \text { X } 100
$$

Knowledge level of the farmers about improved production practices of wheat before frontline demonstration implementation and after implementation was measured and compared by applying paired t-test at 5\% level of significance. Further, the satisfaction level of respondent farmers about extension services provided was also measured based on various dimensions like training of participating farmers, timeliness of services, supply of inputs, solving field problems and advisory services rendered, fairness of scientists, performance of variety demonstrated and overall impact of FLDs. The selected respondents were interviewed personally with the help of a pre-tested and well structured interview schedule. Client Satisfaction Index was calculated as developed by Kumaran and Vijayaragavan (2005). The individual obtained scores were calculated by the formula as:

Client Satisfaction Index =

(Totale individual obtained score)

(Maximum score possible)

The data thus collected were tabulated and statistically analyzed to interpret the FLDs results.

\section{Results and discussion}

\subsection{Increase in knowledge}

Knowledge level of respondent farmers on various aspects of improved wheat production technologies before conducting the frontline demonstration and after implementation was measured and compared by applying paired'-test. It could be seen from the Table 1 that farmers mean knowledge score had increased by 33.2 after implementation of frontline demonstrations. The
Table 1: Compression between knowledge levels of the respondents farmers about improved farming practices of wheat $(\mathrm{N}=160)$

\begin{tabular}{cccc}
\hline \multicolumn{3}{c}{ Mean score } & Calculated \\
$\begin{array}{c}\text { Before FLD } \\
\text { implementation }\end{array}$ & $\begin{array}{c}\text { After FLD } \\
\text { implementation }\end{array}$ & $\begin{array}{c}\text { Mean } \\
\text { difference }\end{array}$ & "t value \\
\hline 36.3 & 69.5 & 33.2 & $8.63^{*}$ \\
\hline "Significant at 5\% probability level & &
\end{tabular}

Table 2: Extent of farmers satisfaction of extension services rendered $(\mathrm{N}=160)$

\begin{tabular}{lcc}
\hline Satisfaction level & Number & Percent \\
\hline Low & 21 & 13.13 \\
Medium & 108 & 67.50 \\
High & 31 & 19.38 \\
\hline
\end{tabular}

increase in mean knowledge score of farmers was observed significantly higher. As the computed value of 't-test' (8.63) was statistically were significant at 5\% probability level. The results are at par with Meena and Singh (2017) on wheat crops, Singh and Sharma (2004) on mustard crop, Singh et al. (2007) on different crops like soybean, pigeon pea, black gram, Dhaka et al. (2010) on mothbean crop, Meena et al. (2016) on wheat crop and Rathod et al. (2016). It means there was significant increase in knowledge level of the farmers due to frontline demonstration. This shows positive impact of frontline demonstration on knowledge of the farmers that have resulted in higher adoption of improved farm practices. The results so arrived might be due to the concentrated educational efforts made by the scientists. The findings confirm with the finding of Ashiwal and Hussain (2008).

\subsection{Farmer's satisfaction}

The extent of satisfaction level of respondent farmers over extension services and performance of demonstrated variety was measured by Client Satisfaction Index (CSI) and results presented in Table 2 . It is observed that majority of the respondent farmers expressed medium $(67.50 \%)$ to the high $(19.38 \%)$ level of satisfaction for extension services and performance of technology under demonstrations whereas, very few 13.13 per cent of respondents expressed lower level of satisfaction. The results are in close conformity with the results of Raj et al. (2013) on pulses crops, Meena and Singh (2014) on gram crops and Dhaka et al. (2010) on mothbean crop. The medium to higher level of satisfaction with respect to services rendered, linkage with farmer's and technologies demonstrated etc. indicate stronger conviction, physical and mental involvement in the frontline demonstration 
which in turn would lead to higher adoption. This shows that the relevance of frontline demonstrations. It indicates that wheat grown with low yield are identified by low knowledge, un-favorable attitude towards high yielding varieties, low risk bearers with negative perception of wheat production technology. In other wards it may also due to then socio-economic status, lower holdings and unavailability of inputs and credit facilities and to some extent supply and marketing problems. This is a point of concern for research and extension functionaries to disseminate improved wheat production technologies for raising the productivity of wheat at all the levels.

\subsection{Constraints in wheat production}

Farmer's wheat production problems were documented in this study. Preferential ranking technique was utilized to identify the constraints faced by the respondent farmers in wheat production. The ranking given by the different farmers are given in Table 3. A perusal of table indicates that lack of suitable salt tolerance high yielding variety (HYV) (88.3\%) was given the top most rank followed by low technical knowledge (78.9\%), termite infestation $(77.8 \%)$, vagaries of weather $(73.3 \%)$. Based on the ranks given by the respondent farmers for the different constraints revealed that lack of suitable salt tolerance HYV, low technical knowledge, termite infestation are the major constraints to wheat production and followed by wild animals. Other constraints such low or erratic rainfall, low soil fertility post, rust disease infestation, stem rot, weed infestation, water lodging, marketing and were found to reduce wheat production. Among all the constraints, harvest management got least concerns. Other studies Dhaka et al., (2010) and Ranawat et al. (2011) have reported similar problems in wheat production.

\subsection{Performance of FLD}

A comparison of productivity levels between demonstrated varieties and local checks is shown in Table 4. During the period under study, it was observed that the productivity of wheat in Pali district under improved production technologies ranged between 33.9 to 46.2 qha $^{-1}$ with a mean yield of $40.3 \mathrm{qha}^{-1}$. The productivity under improved technologies varied from 38.7 to $46.2,39.4$ to $44.7,34.8$ to 41.1 and 36.0 to $38.9 \mathrm{qha}^{-1}$ for the varieties KRL 210, KRL 213, KRL 19 and KRL 1-4, respectively as against the yield range between 23.3 to 33.1 with a mean of $29.0 \mathrm{qha}^{-1}$ under farmers local practices and varieties during study period. The additional yield of different varieties under improved production technologies over local practices ranged from 7.1 to $16.0 \mathrm{qha}^{-1}$ with a mean of $11.1 \mathrm{qha}^{-1}$ in comparison to local practice and varieties. The per cent increase yield under improved production technologies ranged from 22.5 to 52.9 (KRL 210), 25.6 to 45.2 (KRL 213), 26.6 to 47.7 (KRL 19) and 33.8 to 45.5 (KRL 1-4) in respective years. This increased grain yield with improved production technologies was mainly because of high potential yielding varieties.

The variation in the productivity was also caused unusual delay in sowing in some of the farmer's fields. In fields where delayed sowing was done because of prolonged dry hot spell in the month of November and unavailable of irrigation, the crop growth was restricted. The late sowing crop was subjected to relatively less time span available for plant growth and development. Similar yield enhancement in different crops in front line demonstration has amply been documented by Dhaka et al. (2010), Kumar et al. (2010), Prushottam et al. (2012), Kumar et al. (2014), Tolessa et al. (2017) and Hussain et al. (2018). From these results it is evident that performance of improved salt varieties was found better than the local check under local conditions. Farmers were motivated by results of agro technologies applied in the FLDs trials and it is expected that they would adopt these technologies in the coming years also. Yield of the frontline demonstration trials and potential yield of the different varieties of crop was Table 3: Ranking given by farmers for different constraints $(\mathrm{N}=160)$

\begin{tabular}{clcc}
\hline $\begin{array}{c}\text { S. } \\
\text { No. }\end{array}$ & Constraints & Percentage & Ranks \\
\hline 1 & Lack of suitable salt tolerance variety & 88.3 & I \\
2 & Stem rot diseases & 29.4 & VII \\
3 & Aphid infestation & 47.1 & VI \\
4 & Low soil fertility & 26.7 & X \\
5 & Low technical knowledge & 78.9 & II \\
6 & Wild animals (Blue bulls and wild & 52.6 & V \\
& pigs) & & \\
7 & Vagaries of weather (mid season & 73.3 & IV \\
& high temperature) & 27.1 & VIII \\
8 & Weed infestation & 77.8 & III \\
9 & Termite infestations & 31.5 & IX \\
10 & Water lodging & 25.7 & XI \\
11 & Marketing & 21.4 & XII \\
12 & Post harvest management & & \\
\hline
\end{tabular}


compared to estimate the yield gaps which were further categorized into technology index. The technology gap shows the gap in the demonstration yield over potential yield and it was $11.3 \mathrm{qha}^{-1}$. The observed technology gap may be attributed to dissimilarities in soil fertility, salinity and erratic rainfall and other vagaries of weather conditions in the area. Hence, to narrow down the gap between the yields of different varieties, location specific recommendation appears to be necessary. Technology index shows the feasibility of the variety at the farmer's field. The lower the value of technology index more is the feasibility. Table 4 revealed that the technology index value was 24.4. The findings of the present study are in line with the findings of Sawardekar et al. (2003), Dhaka et al. (2010), Kumari et al. (2017), Verma et al. (2016), Singh and Kumar (2017) and Singh 2017.

The economic feasibility of improved technologies over traditional farmer's practices was calculated depending on the prevailing prices of inputs and output costs (Table $5)$. It was found that cost of production of wheat under improved technologies varied from Rs.23550 to Rs. $25500 \mathrm{ha}^{-1}$ in case of KRL 210, Rs. 23900 to Rs. 24900 ha $^{-1}$ for KRL 213, Rs. 22790 to Rs. 24180 ha $^{-1}$ for KRL 19 and Rs.23700 to $25300 \mathrm{ha}^{-1}$ in case of KRL 1-4 with an average of Rs. 24246 ha $^{-1}$ of improved technologies and with an average of Rs. $22836 \mathrm{ha}^{-1}$ in local practice. The additional cost incurred in the improved technologies was mainly due to more costs involved in the cost of improved seed only. Front line demonstrations recorded higher mean gross returns (Rs. 59267 ha $^{-1}$ ) and mean net return (Rs.35021 ha-1) with higher benefit ratio (2.4) under improved technologies of different improved varieties of wheat as compared to local checks. These results are in line with the findings of Yadav et al. (2007), Narwale et al. (2009), Meena and Dudi (2012), Poonia and Pithia (2011), Rajni et al.(2014), Raj et al. (2013), Dhaka et al. (2016) and Pathak (2018). Further, additional cost of Rs. 1421 ha $^{-1}$ in demonstration has yielded additional net returns of Rs. 16242 ha $^{-1}$ with incremental benefit cost ratio 3.8 suggesting its higher profitability and economic viability of the demonstration. Similar results were also reported

Table 4: Yield of wheat as influenced by improved production technologies and drought tolerance varieties over local practices in farmer's fields (2012-2018)

\begin{tabular}{|c|c|c|c|c|c|c|c|c|c|c|}
\hline \multirow{2}{*}{ Year } & \multirow{2}{*}{ Variety } & \multirow{2}{*}{$\begin{array}{c}\text { Area } \\
\text { (ha) }\end{array}$} & \multirow{2}{*}{$\begin{array}{l}\text { No. of } \\
\text { Demo. }\end{array}$} & \multicolumn{2}{|c|}{ Yield $\left(\right.$ qha $\left.^{-1}\right)$} & \multirow{2}{*}{$\begin{array}{c}\text { Add. Yield } \\
\text { over local } \\
\text { check }\left(\text { qha }^{-1}\right)\end{array}$} & \multirow{2}{*}{$\begin{array}{c}\% \text { increase } \\
\text { over local } \\
\text { check }\end{array}$} & \multirow{2}{*}{$\begin{array}{c}\text { EG } \\
\left(\mathbf{q h} \mathbf{a}^{-1}\right)\end{array}$} & \multirow{2}{*}{$\begin{array}{c}\text { TG } \\
\left.\text { qha }^{-1}\right)\end{array}$} & \multirow{2}{*}{$\begin{array}{r}\text { TI } \\
(\%)\end{array}$} \\
\hline & & & & IP & $\mathbf{F P}$ & & & & & \\
\hline \multirow{2}{*}{2012} & KRL 210 & 12 & 30 & 44.5 & 32.1 & 12.4 & 32.6 & 12.4 & 08.0 & 15.2 \\
\hline & KRL 213 & 12 & 30 & 39.4 & 30.8 & 08.1 & 25.6 & 08.1 & 11.1 & 21.9 \\
\hline \multirow{2}{*}{2013} & KRL 210 & 10 & 25 & 38.7 & 31.6 & 07.1 & 22.5 & 07.1 & 13.8 & 26.3 \\
\hline & KRL 19 & 10 & 25 & 35.2 & 27.8 & 07.4 & 26.6 & 07.4 & 19.8 & 36.0 \\
\hline \multirow{4}{*}{2014} & KRL 210 & 08 & 20 & 42.1 & 28.9 & 13.2 & 45.6 & 13.2 & 10.4 & 24.7 \\
\hline & KRL 213 & 12 & 30 & 44.9 & 31.3 & 13.6 & 43.5 & 13.6 & 05.1 & 11.4 \\
\hline & KRL 1-4 & 10 & 25 & 36.6 & 26.0 & 10.6 & 40.8 & 10.6 & 16.9 & 46.2 \\
\hline & KRL 19 & 12 & 30 & 37.0 & 25.4 & 11.6 & 45.7 & 11.6 & 13.0 & 35.1 \\
\hline \multirow{2}{*}{2015} & KRL 19 & 08 & 20 & 38.7 & 27.7 & 11.0 & 39.7 & 11.0 & 11.3 & 29.2 \\
\hline & KRL 210 & 12 & 30 & 44.8 & 33.1 & 11.7 & 35.3 & 11.7 & 07.7 & 17.2 \\
\hline \multirow{3}{*}{2016} & KRL 210 & 12 & 30 & 45.2 & 31.6 & 13.6 & 43.0 & 13.6 & 07.3 & 16.2 \\
\hline & KRL 213 & 10 & 25 & 40.1 & 29.5 & 10.6 & 35.9 & 10.6 & 10.4 & 25.9 \\
\hline & KRL 19 & 12 & 30 & 34.8 & 26.8 & 08.0 & 29.9 & 08.0 & 15.2 & 30.4 \\
\hline \multirow{3}{*}{2017} & KRL 210 & 12 & 30 & 46.2 & 30.2 & 16.0 & 52.9 & 16.0 & 06.3 & 12.0 \\
\hline & KRL 213 & 08 & 20 & 41.1 & 28.3 & 12.8 & 45.2 & 12.8 & 09.4 & 18.6 \\
\hline & KRL 1-4 & 08 & 20 & 36.0 & 26.9 & 09.1 & 33.8 & 09.1 & 14.0 & 28.0 \\
\hline \multirow{3}{*}{2018} & KRL 210 & 10 & 25 & 45.7 & 31.4 & 14.3 & 45.5 & 14.3 & 06.8 & 12.9 \\
\hline & KRL 1-4 & 08 & 20 & 33.9 & 23.3 & 10.6 & 45.5 & 10.6 & 16.1 & 32.2 \\
\hline & Average & 10.3 & 25.8 & 40.3 & 29.0 & 11.1 & 38.3 & 11.1 & 11.3 & 24.4 \\
\hline
\end{tabular}


Table 5 Cost of cultivation (Rs. ha ${ }^{-1}$ ) net return and benefit cost ratio of wheat as affected by improved production technologies over local practices

\begin{tabular}{|c|c|c|c|c|c|c|c|c|c|c|c|}
\hline \multirow[t]{2}{*}{ Year } & \multirow[t]{2}{*}{ Variety } & \multicolumn{2}{|c|}{$\begin{array}{l}\text { Total cost of } \\
\text { cultivation }\end{array}$} & \multicolumn{2}{|c|}{$\begin{array}{c}\text { Gross return } \\
\left(\mathrm{Rs} \mathrm{ha}^{-1}\right)\end{array}$} & \multicolumn{2}{|c|}{$\begin{array}{l}\text { Net return } \\
\left(\mathbf{R s ~ h a}^{-1}\right)\end{array}$} & \multicolumn{2}{|c|}{ B:C ratio } & \multirow{2}{*}{$\begin{array}{l}\text { Add. Cost of } \\
\text { cultivation }\end{array}$} & \multirow{2}{*}{$\begin{array}{c}\text { Add. Net } \\
\text { returns } \\
\left(\text { Rs.ha }^{-1}\right)\end{array}$} \\
\hline & & IP & FP & IP & FP & IP & FP & IP & FP & & \\
\hline \multirow{2}{*}{2012} & KRL 210 & 23550 & 22100 & 55625 & 40125 & 32075 & 18025 & 2.4 & 1.8 & 1450 & 14050 \\
\hline & KRL 213 & 23960 & 22400 & 53190 & 38500 & 29230 & 16100 & 2.2 & 1.7 & 1560 & 13130 \\
\hline \multirow{2}{*}{2013} & KRL 210 & 24970 & 23600 & 52245 & 39500 & 27275 & 15900 & 2.0 & 1.5 & 1370 & 11375 \\
\hline & KRL 19 & 22790 & 21350 & 47520 & 34750 & 24730 & 13400 & 2.1 & 1.5 & 1440 & 11330 \\
\hline \multirow{4}{*}{2014} & KRL 210 & 25890 & 24200 & 56835 & 36125 & 30945 & 11925 & 2.2 & 1.4 & 1690 & 19020 \\
\hline & KRL 213 & 24080 & 23300 & 61400 & 45385 & 37320 & 22085 & 2.5 & 1.9 & 780 & 15235 \\
\hline & KRL 1-4 & 23700 & 22400 & 53070 & 37700 & 29370 & 15300 & 2.2 & 1.6 & 1300 & 14070 \\
\hline & KRL 19 & 23690 & 22100 & 53650 & 36830 & 29960 & 14730 & 2.3 & 1.7 & 1590 & 21865 \\
\hline \multirow{2}{*}{2015} & KRL 19 & 24252 & 23200 & 56115 & 40165 & 31865 & 16965 & 2.3 & 1.7 & 1052 & 14900 \\
\hline & KRL 210 & 23970 & 22300 & 67200 & 49650 & 43230 & 27350 & 2.8 & 2.2 & 1670 & 15880 \\
\hline \multirow{3}{*}{2016} & KRL 210 & 23780 & 21400 & 67800 & 47400 & 44020 & 26000 & 2.9 & 2.1 & 2380 & 18020 \\
\hline & KRL 213 & 22650 & 21400 & 62155 & 44250 & 39505 & 22850 & 2.7 & 2.0 & 1250 & 16655 \\
\hline & KRL 19 & 24180 & 23600 & 53940 & 40200 & 29760 & 15400 & 2.2 & 1.7 & 580 & 14360 \\
\hline \multirow{3}{*}{2017} & KRL 210 & 24870 & 23200 & 71610 & 46810 & 46740 & 23610 & 2.9 & 2.0 & 1670 & 23130 \\
\hline & KRL 213 & 24900 & 23700 & 63705 & 43865 & 38805 & 20165 & 2.6 & 1.9 & 1400 & 18640 \\
\hline & KRL 1-4 & 24400 & 23500 & 59400 & 44385 & 35000 & 20885 & 2.4 & 1.8 & 900 & 14115 \\
\hline \multirow{2}{*}{2018} & KRL 210 & 25500 & 23100 & 75405 & 51810 & 49905 & 28710 & 3.0 & 2.2 & 2400 & 21195 \\
\hline & KRL 1-4 & 25300 & 24200 & 55935 & 39445 & 30635 & 15245 & 2.2 & 1.6 & 1100 & 15390 \\
\hline \multicolumn{2}{|c|}{ Average } & 24246 & 22836 & 59267 & 42050 & 35021 & 19147 & 2.4 & 1.8 & 1421 & 16642 \\
\hline
\end{tabular}

by Singh and Singh (2009), Dhaka et al. (2010), Mahadik and Talathi (2016), Rathore et al. (2016), Lothwal (2010), Meena and Singh (2017) and Morwal et al. (2018) in wheat crops. The results from the present study clearly brought out the potential of improved production technologies in enhancing wheat production and economic gains in rainfed farming situations conditions of this region of Rajasthan. Hence, wheat production technologies have broad scope for increasing the area and productivity at each and every level.

\section{Conclusion}

It may be concluded that the introduction of salt tolerant wheat varieties on salt affected soil with proper agronomic practices are followed then wheat yield increased by 22.5 to 52.9 per cent. Full adoption of salt tolerant wheat production technology was reported by 67.5 per cent and partially adopted by 13.1 per cent. The major constraints perceived by farmers were salt affected soils followed by lack of suitable salt tolerance variety. If these constraints are managed somehow then farmers can harvest more yield with the same level of input which would definitely improve their socio-economic status through frontline demonstration at real farming situation in Pali district. On the basis of the result obtained in present study that the yield gap between conventional practices and improved production technologies was perceptibly higher, there is urgent need to make stronger extension services for educating the cultivators in the implementation of improved production technology. However, the yield level under FLD was better than the local varieties and performance of these varieties could be further improved by adopting recommended production technologies. Hence, it can be observed that increased yield was due to adoption of high yielding varieties and conducting front line demonstration of proven technologies. Yield potentials of crop can be increased to greater extent. This will subsequently increase the income as well as the livelihood of the farming community. From the above research findings it can be also concluded that the maximum number of the respondents had medium level of knowledge and extent of adoption regarding 
recommended wheat production technology. The study reported lack of suitable salt tolerance HYV as major constraint by the beneficiaries and is ranked first followed by low technical knowledge.

\section{Acknowledgement}

The authors sincerely acknowledge the Director CAZRI, Jodhpur for funding. Scientists and staff of ACRPAL, Jodhpur for their technical support and ATARI, Zone VI, Jodhpur for providing all the facilities

\section{References}

1. Agnihotri RK, LMS Palni and DK Pandey. 2006. Screening of land races of rice under cultivation in Kumaun Himalayan for salinity stress during germination and early seedling growth. Indian Journal of Plant Physiology 11: 262-272.

2. Anonymous. 2018. Rajasthan Agricultural Statistics at a Glance. Directorate of Agriculture, Rajasthan, Jaipur. Pp 56-68.

3. Ashiwal BL and A Hussain. 2008. Demonstration- An effective technology for increasing the productivity of gram. Rajasthan Journal of Extension Education, 16:221-223.

4. Bera AK, MK Pati, and A Bera. 2006. Bassionolide ameliorates adverse effect on salt stress on germination and seedling growth of rice. Indian Journal of Plant Physiology 11:182-189.

5. Dhaka BL, RK Bairwa and B Ram. 2016. Productivity and profitability analysis of black gram (Cv. PU 31) at farmer's field in humid south eastern plain of Rajasthan. Journal of Food Legume 29:71-74.

6. Dhaka BL, BS Meena and RL Suwalka. 2010. Popularization of improved maize production technology through frontline demonstrations in south-eastern Rajasthan. Journal of Agricultural Sciences, $1: 39-42$

7. Hussain N, M Mehdi, N Fatima and SR Dar. 2018. Impact of frontline demonstrations on varietal evaluation of wheat (Triticum aestivum) under cold arid condition of Kargil (JandK). Indian Journal of Hill Farming, 2:54-57.

8. Kumar A, R Kumar, VPS Yadav and R Kumar. 2010. Impact assessment of frontline demonstrations of Bajra in Haryana state. Indian Research Journal of Extension Education, 10:105-108.
9. Kumar S, R Singh and A Singh. 2014. Assessment of gaps in pulse production in Hamirpur district of Himachal Pradesh. Indian Research Journal of Extension Education 14:20-24.

10. Kumaran M and K Vijayaragavan. 2005. Farmers' satisfaction of agricultural extension services in an irrigation command area. Indian Journal of Extension Education, 41:8-12.

11. Kumari K, VK Pyasi and A Sharma. 2017. Impact of Front Line Demonstration (FLD) on Area and Productivity of Wheat Growers in Jabalpur District of Madhya Pradesh, India. International Journal of Current Microbiology and Applied Science 6:2237-2242.

12. Lallu and RK Dixit. 2005. Salt tolerance of mustard genotype at seedling stage. Indian Journal of Plant Physiology 14:33-35.

13. Lothwal OP. 2010. Evaluation of frontline demonstrations on black gram in irrigated agroecosystem. Annals of Agricultural Research, 31:24-27.

14. Mahadik RP and Talathi M S. 2016. Impact of frontline demonstrations organized by Krishi Vigyan Kendra, Roha. Indian Journal of Extension Education and Rural Development 24:162-165.

15. Meena ML and A Dudi. 2012. On Farm Testing of wheat (Cicer arietinum L.) cultivation for site specific assessment under rainfed condition of western Rajasthan. Indian Journal of Extension Education, 48:93-97.

16. Meena KC, TC Verma, S Ashival and IG Gupta. 2016. Popularization of wheat Raj 4037 through FLDs in Baran district of Rajasthan. International Journal of Applied and Pure Science and Agriculture 2:31-36.

17. Meena ML and D Singh. 2011. Impact of frontline demonstration in adoption of improved gram production technology. Indian Journal of Social Research 55:277-283.

18. Meena ML and D Singh. 2016. Productivity enhancement and gap analysis of moth bean through improved production technologies on farmers' participatory mode. Indian Journal of Dryland Agricultural Research and Development 31:68-71.

19. Meena M L and D Singh. 2017. Increasing wheat yield through frontline demonstration in Pali district of Rajasthan. Wheat and Barley Research 10:52-58. 
20. Meena ML and D Singh. 2017. Technological and extension yield gaps in greengram in Pali district of Rajasthan, India. Legume Research 40:187-190.

21. Morwal BR, P Pagaria, SL Kantwa and S Das. 2018. Performance of frontline demonstrations on yield enhancement of cumin in Barmer district of Rajasthan. Journal of Krishi Vigyan 6: 76-78.

22. Narwale SS, AD Pawar, BM Lambade and NS Ugle. 2009. Yield maximization of wheat through INM applied to sorghum-mothbean cropping sequence under irrigated condition. Legumes Research, 32:282285.

23. Pathak J. 2018. Yield performance of soybean (Glycine max L.) in Madhya Pradesh. Journal of Krishi Vigyan 6:253-256.

24. Poonia T C and MS Pithia. 2011. Impact of frontline demonstrations on mothbean in Gujarat. Legume Research, 34:304-307.

25. Purushottam, SK Singh, RN Chaudhary, K Kumar, CS Praharaj and B Krishana. 2012. Assessment of technological inputs for major pulses in Bundelkhan region. Journal of Food Legumes, 25:61-65.

26. Raj AD, V Yadav and JH Rathod. 2013. Impact of frontline demonstrations (FLD) on yield of pulses. International Journal of Scientific and Research, 3:1-4.

27. Rajni, NP Singh and P Singh. 2014. Evaluation of frontline demonstrations on yield and economic analysis of summer mungbean in Amritsar district of Punjab. Indian Journal of Extension Education, 50:87-89.

28. Ramden HA, SA Niemi and YKA Hadathi. 1986. Salinity and seed germination of corn and soybean. Iraqi Journal of Agricultural Science 4:97-102.

29. Ranawat Y, H Ram, SS Sisodiya and NK Punjabi. 2011. Adoption of improved maize cultivation practices by trained and untrained farmers of KVK, Udaipur. Rajasthan Journal of Extension Education, 19:144-147.

30. Rathod AD, S Hadiyal and BS Rajawat. 2016. Adoption behavior and constraints in wheat production technologies in saline area of Gir Somnath district of Gujarat. International Journal of Forestry and Crop Improvement 7: 52-56.
31. Rathore RS, RL Solanki and SS Sisodia. 2016. Impact of frontline demonstrations on cluster bean production in farmers' field. Indian Journal of Extension Education and Rural Development, 24:52-54.

32. Samui SK, S Maitra, DK Roy, AK Mondal and D Saha. 2000. Evaluation of front line demonstration on groundnut (Arachis hypogea L.) in Sundarbans. Journal of Indian Society of Coastal Agricultural Research, 18:180-183.

33. Sawardekar SV, SS Dhane and BB Jadhav. 2003. Front-line demonstration performance of salt-tolerant rice varieties in coastal saline soils. IRRN, 28:73-74.

34. Singh A and AK Singh. 2009. Yield advantages in pulses at farmers' field. Journal of Food Legumes 22:198-201.

35. Singh DK, US Gautam and RK Singh. 2007. Study on Yield Gap and Level of Demonstrated Crop Production Technology in Sagar District. Indian Research Journal of Extension Education, 7:94-95.

36. Singh N and S Kumar. 2017. Yield enhancement and popularization of improved production technologies in wheat through frontline demonstrations. International Journal of Advanced Biology Research 7(1):81-84.

37. Singh SB. 2017. Impact of frontline demonstrations on yield of wheat (Triticum aestivum) under rain fed condition in Uttarakhand. International Journal of Science, Environment 6:779-786.

38. Tolessa D, A Soloman, G Wudineh, M Rahima, L Wasihun and L Wondimu. 2017. Dissemination of improved technologies based on innovation platform approach for sustainable wheat production in Ethiopia. International Journal of Agricultural Innovation Research 6:123-134.

39. Yadav VPS, R Kumar, AK Vashishtha and SL Bhela. 2007. Boosting the pulse production technology through frontline demonstrations. Indian Research Journal of Extension Education, 7:12-15.

40. Verma AK, KL Jeengar, J Ram and KC Nagar. 2016. Popularization of high yielding varieties of wheat in Jhalawar district of Rajasthan state through frontline demonstrations. Journal of Wheat Research 8(1):39-44 